\title{
Memory, Magic and Militias: Cora Indian Participation in Mexico's Wars, from The Reforma to The Revolution (1854-1920)
}

\author{
Nathaniel Morris, \\ University College, University of London \\ 29 Archbishop's Place, London, SW2 2AH \\ n.morris@ucl.ac.uk
}

\begin{abstract}
Mexico's Cora Indians have played an outsized role in national history, thanks to their skilful use of guerrilla tactics and success in forging strategic alliances with outside forces in defence of their cultural, territorial and political autonomy. Cora participation in elite struggles between Liberals and Conservatives (1850-73), and subsequently in the Mexican Revolution (1910-20), helped to shape the way that both conflicts played out in Western Mexico. Such participation also allowed Cora communities to keep hold of traditional landholdings in the face of political and economic reform, while sowing the seeds for the foundation of the Mexican state of Nayarit.
\end{abstract}

KEY WORDS: Cora Indians, Nayarit, Mexico, Insurgency, Autonomy, War of Reform, French Intervention, Mexican Revolution, Guerrilla Tactics

The Cora Indians - or, in their own tongue, Naayari - are an Uto-Aztecan people native to the mountains of north-west Mexico who today number around 30,000 individuals. They earned a reputation as fierce fighters during the Colonial period, and held out against the Conquistadores until 1722, when their priest-kingdom was amongst the last of Mexico's native polities to fall to Spanish forces. For a small people - who in the late nineteenth century numbered between three and five thousand individuals - the Coras have played an outsized role in Mexican history both at regional and national levels, thanks to their skill as guerrilla fighters, their relative unity as a people, and their determined efforts to preserve their cultural, territorial and political autonomy, often via strategic alliances with outside forces.

To this end the Coras took part in the Mixtón war of 1532-42 between the Spaniards and an alliance of rebellious western Mexican tribes; held up the conquest of their homeland and nearby regions until the seventeenth century; and played an important regional role as insurgent fighters during the independence struggles of the early 1800s. Above all, however, this article will focus on the hitherto little-studied issue of Cora participation in the conflicts that wracked Mexico from the Liberal 'Reform' era of the 1850s, to the end of the Mexican Revolution in 1920: a tumultuous period that saw wars between Conservative and Liberal factions of the national elite; between the nascent Mexican nation-state and the forces of Maximilian's French empire; between a consolidated Liberal dictatorship and revolutionary insurgents; and, in the western Mexican state of Jalisco, between local elites based in the small trading city of Tepic (which lay close to the Cora homeland), and those of the state capital, Guadalajara, far away to the south.

Although portrayed by nineteenth-century politicians, journalists and scholars alike as either 
apolitical 'savages' isolated in their mountain strongholds, ${ }^{1}$ Cora fighters came to make up the backbone of the agrarian army of bandit-turned agrarian revolutionary Manuel Lozada. For reasons distinct from those of Lozada's mestizo followers (whom historians have tended to uncritically lump together with the Coras to form a homogeneous, 'agrarista' mass) ${ }^{2}$ the support of independent-minded Cora communities for Lozada helped him carve an autonomous peasant republic out of northern Jalisco between 1854 and 1873, while concurrently helping to shape the course of the French Intervention in western Mexico from 1861-1867, and sowing the seeds for the separation from Jalisco of their homeland and the surrounding areas, which became a federally-administered military district. After Lozada's final defeat and death in 1873, some Coras switched sides and helped to prop up the local rule of the Liberal central government; while others took part in local uprisings that allowed their communities to keep hold of traditional landholdings in the face of Liberal reforms and the colonisation attempts of Spanish-speaking mestizo Mexicans. ${ }^{3}$ Finally, at the outbreak of the Revolution in 1910, a few Cora individuals joined the insurgent forces fighting to overthrow Porfirio Díaz. Their involvement - which, with the exception of this author's own work, has been little examined by historians ${ }^{4}$ - paved the way for their more systematic participation in the civil wars between rival revolutionary factions that consumed the country between 1914 and 1920. At national level, this participation helped the Carrancistas to defeat their Villista enemies and cement their control over Mexico, and also won the Cora homeland and nearby regions the status of a new Mexican state, named 'Nayarit' after the Coras' own name for themselves.

\section{Pagan Priest-Kingdoms and Cora Costumbre}

The Cora homeland - or 'Sierra Cora' - forms part of Mexico's Sierra Madre Occidental mountain range. Spanning a total area of some 5,000 km2, it is located almost completely within Nayarit, making up nearly eighteen percent of the state's total area, including some or all of the municipalities of El Nayar, La Yesca, Acaponeta, Huajicori, Ruíz and Rosamorada. The volcanic plateaus that dominate the region are overlooked by peaks that rise up to $3,340 \mathrm{~m}$ above sea level, and are cut through by rivers whose canyons drop down to around $400 \mathrm{~m}$ above sea level. Areas above $1000 \mathrm{~m}$ are temperate, while at lower altitudes the prevailing climate is sub-tropical and often extremely hot. The climate also fluctuates between a wet season between June and September, and a harsh dry season that lasts from October until May.

\footnotetext{
${ }^{1}$ González, Ensayo estadístico y geográfico de Territorio de Tepic, 560; Cambré, La Guerra, 496; see also the numerous articles attacking Lozada and his supporters in Le Trait d'Union and Juan Panadero from the mid1850 s onwards

${ }^{2}$ The best examples of this tendency can be seen in the work of Rendón: cf. Rebelión Agraria de Manuel Lozada and Manuel Lozada y las comunidades indigenas. A notable and comprehensive exception to this approach is to be found in the work of Regina Lira, who has recently carried out in-depth research into Cora and Huichol participation in Lozada's movement, showing that their support cannot be separated from the ethno-cultural, ritual-political and historical idiosyncrasies of each people, and, indeed, of each of the numerous communities between which they are divided. Cf. Lira, 'De Buenos mexicanos.'

${ }^{3}$ In the Cora homeland and nearby regions, mestizos are primarily defined as all those local people who do not speak an indigenous language or take part in indigenous rituals. Other criteria by which Mexican mestizo identity can or should be judged vary from region to region, and are often controversial; for in-depth studies of Mexican 'mestizaje' see Lomnitz-Adler, Exits From the Labyrinth; Bonfil, México profundo; Friedlander, Being Indian in Hueyapan

${ }^{4}$ cf. Morris, ‘Creating the World Anew,' and ““¿Forjando Patria?” Las políticas del Estado revolucionario y el ocaso de los vínculos intercomunales coras en la Sierra del Nayar'
} 

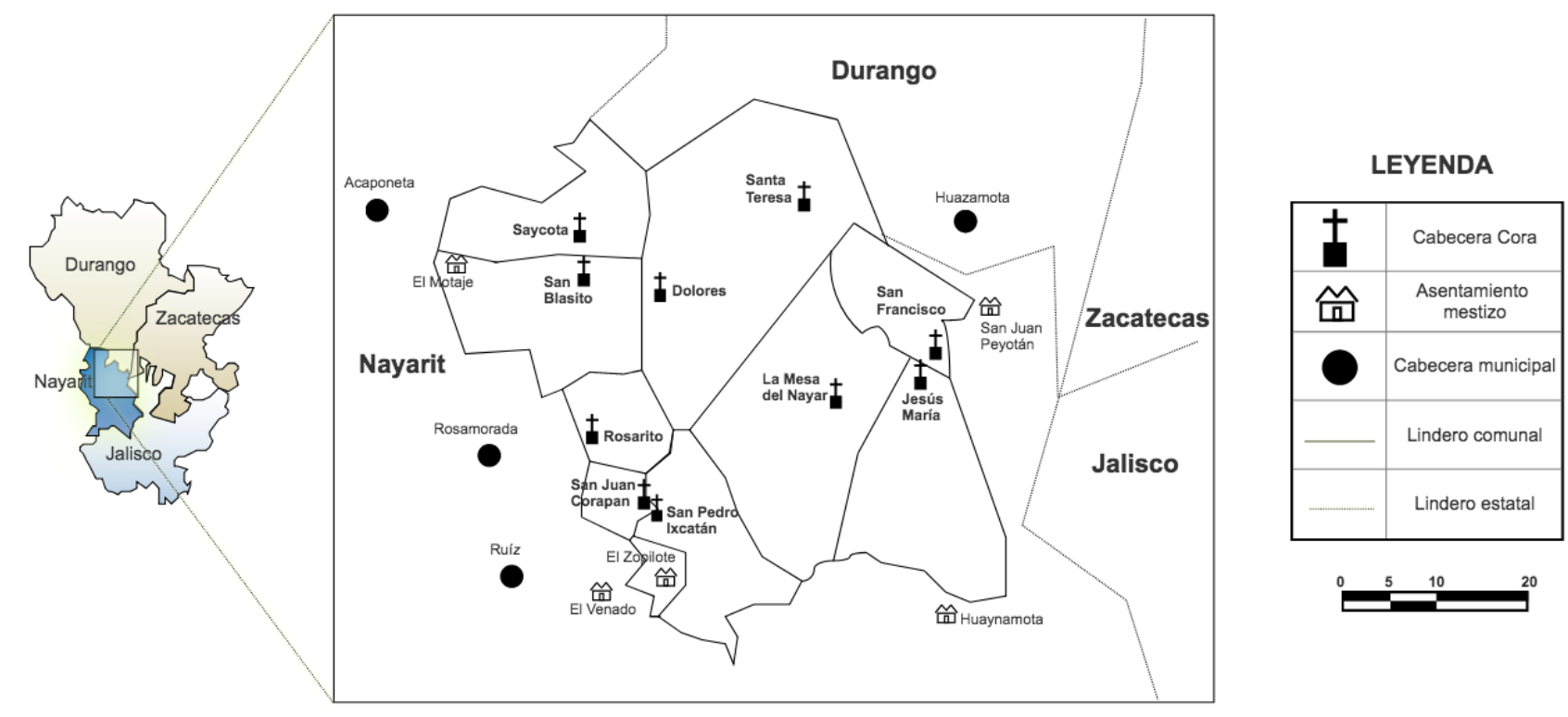

The Coras themselves are a people forged in war. During the early sixteenth century, in the context of the upheaval caused by the arrival of the Spaniards in what is now western Mexico, the Coras' ancestors, previously divided between numerous smaller polities, united under the rule of a single politico-religious leader known as the 'Tonatí,' or 'Rey Nayar.' The inhabitants of this priest-kingdom included not only recalcitrant or apostate Indians from across western Mexico, but also escaped African slaves and renegade mulattos and Spaniards. ${ }^{5}$ Although neither Catholic missionaries nor Spanish soldiers were permitted to enter the Tonatí's kingdom, which remained independent of Spanish rule until 1722, his subjects traded in salt and livestock with the inhabitants of nearby coastal regions, and some worked seasonally in the mines of Durango and Zacatecas. ${ }^{6}$

As a result of such contacts, the Tonatí's people became adept at blacksmithing and raising (and raiding) cattle, horses and mules, and also began to adopt elements of the Catholic faith into the framework of their own customary practices (which they refer to, in Spanish, as costumbre). ${ }^{7}$ However, the Cora priest-kingdom was ultimately held together by resolutely non-Christian costumbre, including ritual dances called mitotes practiced at the level of both descent-groups and entire communities; faith in the power of ancestors and pre-Hispanic gods; cyclical conceptions of history; and a belief that shifting subsistence agriculture, hunting, and gathering were sacred activities in which all 'real people' - that is, the Coras and their indigenous neighbours, the Huichols, Tepehuanos and Mexicaneros - were obliged to participate. Throughout the sixteenth and seventeenth centuries, mass mitote ceremonies which at this point featured human sacrifice - were overseen by the Tonatí at La Mesa, which became the focal point of a 'centralized political and religious tradition' ${ }^{8}$ uniting a population organised at a lower level into clans or descent-groups defined - as they continue to be today - by blood-ties and participation in family-level mitotes (which coincide with the stages of both the agricultural year and the human life cycle). ${ }^{9}$ Although the military capacity of this unified population was key to their resistance to Spanish attempts to conquer them, Colonialera missionaries and soldiers preferred to use geography to explain the continued independence

\footnotetext{
${ }^{5}$ Coyle, From Flowers to Ash, 75

${ }^{6}$ Neurath, Las fiestas, 21 ,

${ }^{7}$ Hinton, 'Pre-Conquest Acculturation,' 166

${ }^{8}$ Coyle, From Flowers to Ash, 82

9 Jáuregui, Los coras, 12
} 
of the Tonatí's kingdom, ${ }^{10}$ describing the region as 'furious and horrible... It is not even possible to ride horseback in this country as the abruptness of the terrain is hard on the horses and the steepness of the slopes frightens the horsemen.' 11

As mentioned above, the Cora priest-kingdom was the last Indian kingdom in Mexico to fall to Spanish forces, two centuries after the conquest of the Aztec empire. ${ }^{12}$ However, even after Jesuit missionaries congregated the conquered Coras into missions at Jesús María, La Mesa, Santa Teresa, San Juan Peyotán, San Juan Corapan, Rosarito, Huaynamota, and San Pedro Ixcatán, they continued to practice pan-communal rituals that facilitated the political and military cohesion of the Cora population as a whole. ${ }^{13}$ Within each of the new mission settlements - some of which doubled as Spanish military garrisons - the cults of statues of Catholic saints - known as santitos - were also absorbed into Cora costumbre. ${ }^{14}$ Even after the Coras returned to their dispersed ranches following the expulsion of the Jesuits from Mexico in 1767 , they continued to use the missions and their churches 'as ceremonial and assembly centres. ${ }^{15}$ By the late eighteenth century, the Coras thus possessed 'a half-digested Christianity but a well organised and functioning civil-religious hierarchy, ${ }^{16}$ which held together their disparate descent groups and diverse, autonomous communities in the absence of the centralised rule of the Tonatí. This allowed them to continue to mobilise effectively against external threats, often 'taking advantage of the disputes between Spanish authorities to establish inter-ethnic and also inter-class alliances,' as demonstrated by wholesale Cora partipation in wider regional rebellions in $1723,1724,1758$, and $1801 .{ }^{17}$

\section{The Mexican War of Independence and the Rebellion of Manuel Lozada}

Less than a hundred years after the conquest of the Tonatís kingdom, the outbreak of the War of Mexican Independence in 1810 provided the Coras with yet another opportunity to use their skills as guerrilla fighters to claim autonomy for themselves and their communities. The majority of the Cora population supported regional pro-independence forces, and although a Franciscan royalist did his best to organise the defence of the Sierra, he was soon forced to flee the region in the face of the Cora insurgents' superior numbers. ${ }^{18}$ More than a decade of local fighting followed this early defeat, during which both the royalist and pro-independence sides employed guerrilla tactics during six-month campaigning seasons that, in line with Cora costumbre, started not in October, with the harvest, but rather in November, after ceremonies that rendered the corn crop edible had been celebrated. The local campaigning season meanwhile ended at the beginning of the rains, in May, when the Sierra became impossible for Royalist cavalry to negotiate. For the Coras, rituals also defined the timings of military offensives, and shaped preparations for raids, or measures to defend communities from raiders. Even the directions in which civilians fled from their attackers were informed by older routes of pilgrimage, which linked the communities of the Sierra Cora to the sacred caves and forest groves that now became the hideouts of Cora families.

Royalist forces, in order to survive in the harsh terrain of the Sierra, and, they hoped, cut off

\footnotetext{
${ }^{10}$ Coyle, 'The Customs,' 516

${ }^{11}$ Ortega, in ibid.

12 Gerhard, La frontera Norte, 142-5

13 ibid., p. 147; Gómez, 'Huicot,' 138

${ }^{14}$ Hinton, 'Indian Acculturation,' 22

${ }^{15}$ Coyle, From Flowers, 85

${ }^{16}$ Hinton, 'Indian Acculturation,' 22

${ }^{17}$ Lira, 'De buenos mexicanos,' 7

18 Jáuregui, Magriñá, 'Estudio etnohistórico,' 64-6
} 
supplies to their enemies, focused their energies on 'confiscating all of the grain which the Coras had stored... and capturing their cattle.' ${ }^{19}$ But Cora fighters saw off such threats by 'making a fearful noise and launching a rain of rocks and arrows down upon the soldiers, after which they vanished. ${ }^{20}$ The use of rocks and boulders as weapons of war is, of course, as ancient as war itself, and has been used to great avail by guerrilla forces across the world; perhaps most famously in the Battle of the Roncevaux Pass in 778, when, as commemorated in the medieval 'Chanson de Roland,' Basque guerrillas obliterated the rearguard of Charlemagne's Imperial army as it passed through their territories. Such tactics remained extremely effective in the mountainous Cora homeland - especially against outsiders who were unaccustomed both to the local terrain and the rigours of guerrilla warfare - and Cora fighters continued to use them with success throughout the rebellion of Manuel Lozada, and into the twentieth century.

In 1821, thanks in large part to the support of indigenous groups like the Coras, the insurgents finally won the day against the Spaniards and established the new, independent nation of Mexico in place of the Spanish colony of 'New Spain.' But the defeat of royalist forces did not mean that the Coras would return to their previous status as supposedly 'conquered' Indians. Instead, Cora participation in local uprisings and their canny political manoeuvring in the context of national-level conflicts between Liberals and Conservatives for control of the young nation allowed them to prevent government officials and Catholic priests alike from asserting control over their communities. ${ }^{21}$

In particular, Cora support for the revolutionary movement of mestizo peon-turned-bandit chief and agrarian reformer Manuel Lozada - who ruled the area that is today the state of Nayarit as an independent peasant republic between 1853 and 1873 - allowed the Coras to continue to maintain their political and religious autonomy into the $1870 \mathrm{~s}$. Thus they were able to avoid the most deleterious effects of the mid-century Liberal Reform Laws, which, seeking to create a nation of prosperous smallholders from a country still dominated by corporations, mandated the division and distribution of communal and Church-owned lands, opening up traditionally Indian territories across Mexico for purchase by speculators and large landowners.

Manuel Lozada rose to power on the back of his opposition to these reforms, which garnered him widespread popular support throughout the Seventh Canton of Jalisco. From humble beginnings as a bandit, in 1856 Lozada gained political prominence through an alliance with a Conservative faction of the commercial elite of Tepic, the Seventh Canton's capital city. In exchange for helping these Conservatives in their fight against both the Liberals of Tepic and those of Jalisco's state capital, Guadalajara, they kept Lozada well supplied with cash, arms and powder, and 'capitalised on the discontent of the Cora communities... which they channelled into a struggle for the defence of the conservative national project that began to take shape during those years. 22

However, Lozada and his local followers - made up of mestizos and Cora and Huichol Indians - proved more independent-minded than their new Conservative allies had envisaged. Lozada followed perfectly the trajectory of the social bandit as outlined by Hobsbawm - 'outlaws whom the state regards as criminals, but who are considered by their people as heroes, as champions, avengers, fighters for justice, perhaps even leaders of liberation,' and who, in

\footnotetext{
${ }^{19}$ Santoscoy, Colección de documentos, 62

20 ibid., 63

${ }^{21}$ Coyle, From Flowers to Ash, 88

${ }^{22}$ Lira, 'De buenos mexicanos,' 11
} 
societies resisting the "encroachments and historical advances of central governments... may even be helped and supported by the local lords. ${ }^{23}$ As well as attacking Liberal militias and federal troops, Lozada helped his followers take back territory lost due to the Liberal Reform, and to defend other lands threatened by these same laws; in the Sierra Cora, Lozada's support enabled a 'multitude of indigenous rebels' to attacked mestizo colonists who had begun to seize Cora lands around the community of Jesús María. They killed some of them, forced the rest to flee the region 'in the greatest misery,' and took the local priest prisoner, on the grounds that he had encouraged mestizo settlers and tried to curb Cora religious autonomy. ${ }^{24}$ In response to these and numerous other perceived 'outrages,' Federal troops and Jalisco's state militia intervened in the late 1850s on behalf of landowners attacked by Lozada's supporters, whom they pursued them deep into the mountains of the Sierra Cora. The sudden appearance of government soldiers in their homeland only increased Cora support for Lozada. In 1858, the comisario municipal de San Juan Peyotán reported that all of the Cora communities, without exception, "have declared in favour of "the wicked Lozada.", 25

Cora guerrillas proved an invaluable addition to Lozada's forces. Their hit-and-run tactics terrified government forces struggling to penetrate the 'rocky and heavily forested terrain' of the Sierra. ${ }^{26}$ Just as they had done a few decades before, during the struggle for Mexican independence, Cora fighters responded to the Federals' bullets and futile artillery barrages with primitive but effective weapons such as boulders: 'The cyclopean rock, the enormous mass of granite, is detached, using levers, from its socket... and flies, pushed by unseen hands, knocking down horses and not stopping until it reaches the foot of the mountain, clotted with blood and splattered brains. ${ }^{27}$ They also used fire against their enemies to great effect, taking advantage of the aridity of the Sierra during the local campaigning season, which coincided with the driest months of the year. The Mexican novelist Mariano Azuela, in a short story based on his reading of reports on Lozada's rebellion, describes in terrifying detail a night-time ambush of government forces, during which Cora guerrillas set alight the scrub surrounding their enemies' camp. As the flames lit up the darkness of the mountains, bullets flying amidst the panicked men and burning horses, one survivor reminisced that 'no eramos gente, señor, sino demonios en el infierno. 28

Frustrated by these attacks, as well as by 'the apathy and lack of cooperation of the inhabitants of the Canton, ${ }^{, 29}$ Lozada's enemies demanded that Jalisco's state congress authorise their complete destruction of Lozada's main strongholds - including several of the Cora communities of the Sierra - and the dispersal of all their inhabitants, "who in their totality are composed of bandits who have desolated the Canton, sowing death, dishonour, misery and terror and every class of the post punishable iniquity throughout. ${ }^{30}$ The congress refused, however, and in autumn 1857 Jalisco's Liberal leaders agreed a truce with Lozada, according to which his supporters - no longer classed as 'bandits' but as 'indigenous rebels,' the change of tone reflecting the change of government strategy - were to give up their arms, in exchange for individual pardons and Guadalajara's pledge to 'carry out the measuring, surveying, and demarcation of the lands of the haciendas of this Canton, in virtue of the question of territory

\footnotetext{
${ }^{23}$ Hobsbawm, Bandits (London, 2000), 20

${ }^{24}$ Lira, 'De buenos mexicanos,'.21

25 ibid.

${ }^{26}$ Meyer, Manuel Lozada, 239

${ }^{27}$ Ibid 220, 239 and 331

28 ibid., 223 quoting Azuela, 'El Hombre Masa,' 409-10

${ }^{29}$ AHJ, Seguridad Pública, Rocha to Parrodí, 2 Oct. 1857

${ }^{30}$ Ibid.
} 
being the cause of this uprising. ${ }^{31}$

Jalisco's Liberals refused to offer Lozada himself an amnesty, however, and instead condemned him for causing 'a scandal infringing the law and offending the most basic moral principles,' and for committing 'crimes of all kinds at multiple junctures and without any political project. ${ }^{32}$ Lozada therefore remained under arms, and soon threw himself and his supporters into the new conflict between Liberal and Conservative elites - the 'War of Reform' - that broke out a few weeks later. Lozada and Carlos Rivas - the scion of an elite Conservative family in Tepic and Lozada's second-in-command - 'organised in the Sierra, the valleys and the lowlands the contingents that would make up the Conservative forces in the Seventh Canton. ${ }^{, 33}$ Just like contemporary Yeke warlords of Central Africa described elsewhere in this volume - who in the 1870s took advantage of an alliance with Portuguese traders to found an independent state in Congo's Katanga region ${ }^{34}$ - Lozada's supposedly 'backward' followers owed much of their political and military success to their homeland's incorporation into global trade networks, which had enabled a clique of regional families, 'organised around the commercial interests of the Barrón y Forbes trading house of Tepic,' to amass sufficient wealth to fund Lozada's insurgency. ${ }^{35}$ But the support of so many Coras for Lozada enabled Liberal journalists and politicians to condemn his cause as a 'caste war' that aimed at the 'destruction of the white race,' building on Colonial ideas of the mountains of Nayarit as a remote and impenetrable bastion of savagery. ${ }^{36}$

However, while dismissed as an outburst of 'barbarism' by Mexico's Liberal elites, regarded by the nation's Conservative leaders and their wealthy partisans in Tepic as a local extension of their own movement, and represented more recently by many historians as the near spontaneous uprising of a disaffected and homogeneous 'indigenous peasantry, ${ }^{, 37}$ the rebellion of Lozada and his supporters - grouped together as 'the United Pueblos of Nayarit' - was in fact a far more complex affair. In aiming to restore to the Seventh Canton's formerly influential peasant communities the lands and political and religious autonomy they had lost to Liberal reforms, it was more than just another outburst of rural discontent: as scholars such as Meyer have shown, it was in fact a movement whose declared political goals outlined an alternate model of state-formation for elites seeking to create a new Mexican nation from the ground up. ${ }^{38}$ Rather than seeking to destroy the country's indigenous and peasant communities, and their traditions of local rule and direct democracy, Lozada's political model envisaged these corporate entities as the building blocks from which the new nation could be fashioned. In line with this model, Cora support for the movement was harnessed under one of their own: Dionisimo Gerónimo, a Cora warlord from La Mesa, the old capital of the Cora priest-kingdom. Gerónimo acted as the chief politico-military leader of a league of autonomous Cora communities, internal control of which was shared by elderly ritual specialists, middle-aged

\footnotetext{
${ }^{31}$ AHJ, Seg. Púb., Convenios de Paso de Caimán, 15 Nov. 1857

${ }^{32}$ Ibid.

${ }^{33}$ Lira, 'De buenos mexicanos,' p.21

${ }^{34}$ cf. Giacomo Macola, 'Guerrilla Warfare in Katanga: The Sanga Rebellion of the 1890s and Its Suppression', in this issue

${ }^{35}$ Lira, 'De buenos mexicanos,' 21

${ }^{36}$ Quevedo y Zuvieta, México, 140; see also Van Oosterhout, 'Popular Conservatism,' 221-2

37 cf. A. Aldana Rendón, Rebelión Agraria de Manuel Lozada; Rendón, Manuel Lozada y las comunidades indígenas; Rugerio, 'La Revuelta Agraria de Manuel Lozada y la Separación de Tepic."
}

38 cf. Esperando a Lozada; Meyer, La Tierra de Manuel Lozada Vol. IV: Colección de Documentos para la Historia de Nayarit; Meyer, Manuel Lozada 
members of directly democratic cargo-systems governments, and communal 'military commands' headed by 'Indians named by Lozada.' ${ }^{39}$ All of these assorted political and military authorities were furthermore subject to the overall, centralised control of a single 'governor of the Indian territory' elected once a year, on 15 January, ${ }^{40}$ a system legitimised by the development and formalisation of complex internal, and also inter-communal, ritual practices.

Although Cora participation in the 'United Pueblos' movement 'implied subjecting themselves militarily to Lozada's General Command in [the lowland village of] San Luis, and politically to its political captaincy in Tepic,' the recent work of Regina Lira demonstrates that the Coras' own internal politico-military organisation in many ways echoed arrangements in the Sierra in the late eighteenth century, when each Cora community had fielded a militia that answered to a central military command in Jesús María. During the Lozada era, each of the Cora communities continued to contribute its contingent to a combined Cora militia force, maintaining 'a list of men old enough and in good enough physical condition to fight, ten percent of whom remained always at arms, according to a system of rotation that guaranteed a minimal but permanent mobilisation, as well as the entire contingent's familiarity with military practices.' Each community also took care of feeding its militia, and ensured they were wellarmed with 'a lance, sword, machete, dagger, pistol and rifle.' The only difference was that now, the Cora militias were organised around two military commands: one, as before, in Jesús María, with a second established in Dionisio Gerónimo's stronghold of La Mesa, each of which was overseen by a council 'composed of a military commander who functioned as president, and two subordinate captains who served as secretaries. ${ }^{41}$

Between late 1857 and late 1860, Lozada and the United Pueblos battled for control of the Seventh Cantón against Liberal guerrillas led by Lozada's nemesis, Ramón Corona. Although at local level the latter found it impossible to overcome 'la enormous resistance... offered by the mountainous terrain he trod and the warlike race he tried to subjugate, ${ }^{, 42}$ by the end of 1860, the war had been won at national level by the Liberals, who took power in Mexico City and installed Benito Juárez as President of the Mexican Republic. In the Seventh Canton, which Conservative leaders had earlier declared independent of Jalisco in exchange for Lozada's support, Lozada proclaimed his submission to the Liberals and looked to sign an armistice with Juárez and his new government. He had demonstrated little real ideological attachment to the Conservative cause beyond a shared antipathy to the Liberals, to whom he was nevertheless now willing to claim fealty; his real interest lay in maintaining his influence in the Seventh Canton, now in a limbo between independence and re-incorporation.

However, Lozada refused to give up his weapons, while the new, Liberal Governor of Jalisco, Pedro Ogazón, refused to acknowledge any directives issued in the Seventh Canton before the Liberal victory. Negotiations between the two sides quickly broke down, and in February 1861 Ogazón declared that anyone who did not immediately and unconditionally submit to his government would be 'considered as bandits' and 'irrevocably shot at the moment of their apprehension,' while ordering the forces he sent to the region, composed of five thousand men, ${ }^{43}$ to completely destroy Lozada's strongholds and distribute their property amongst their neighbours. ${ }^{44}$

\footnotetext{
39 'Periódico Oficial 1878,' in Meyer, De cantón de Tepic, 158

${ }^{40}$ Alicia Hernández Chávez, 'Lozada no muere,' in ibid., 211

${ }^{41}$ Lira, 'De buenos mexicanos,' p.23, citing Meyer, Manuel Lozada, 240-241; 251-254

${ }^{42}$ Quevedo y Zuvieta, México, 65

${ }^{43}$ Lira, 'De Buenos Mexicanos,' 22

${ }^{44}$ ABPE, Colección de leyes y decretos de Jalisco, 1860-61, 20
} 
There followed another year of harsh warfare in the Sierra Cora. The anti-Lozada tradition consistently ignores the savagery of the Liberal campaign, as outlined by Ogazón's above decree, or bandit-turned-Liberal commander Antonio Rojas' plan to invade the Cora homeland and 'not leave before exterminating this accursed race of bandits... and throw from their homes these Indians and push them into the neighbouring states. ${ }^{45}$ Even these measures could not end the war in the Seventh Canton decisively for the Liberals, "unable to land the decisive blow because the Indians roam from hill to hill." 46 But it was only after the arrival of French, British and Spanish troops near Veracruz early in 1862 that they agreed to negotiate with Lozada's forces.

The ostensible aim of the foreign expeditionary force was to collect on unpaid debts that Mexico had racked up during the War of Reform; but before long the French decided to mount a full-scale invasion of the troubled republic, in order to establish in its place a profitable monarchical protectorate - the so-called 'Second Mexican Empire' - under an Austrian prince, Maximillian of Hapsburg. In the face of this new threat to Liberal power, General Ogazón met with Lozada, who, in clear acknowledgement of his cause's coherent local political and socioeconomic objectives, agreed to demobilise his forces in exchange for an amnesty for his supporters, and the formation of a new, neutral Canton-wide government, which would ensure 'the defence of the Indians in territorial conflicts with the neighbouring landowners.' 47

Despite this treaty, however, Liberal attempts to return the Seventh Canton to Guadalajara's control continued. Lozada's arch-enemy, Ramón Corona, moved large numbers of troops in and out of the region, while positions in the new Cantonal authority were given to Lozada's old Liberal opponents, who enacted a plan to colonise the Sierra Cora with armed American settlers. ${ }^{48}$ These would be given land and other economic incentives in exchange for their 'service against the Indians when thus required by the nation's government. ${ }^{49}$ In the midst of the French intervention at national level, but faced with the potential of a rather more threatening foreign invasion on his own doorstep - that of American settlers committed to destroying the Coras - Lozada was forced to accept that the Liberals had reneged on their treaty commitments, and in August 1863 instead recognised as Mexico's legitimate government the Emperor Maximilian and his French backers, who were now ensconced in the interior of the country.

During the five years of war between Maximilian, French expeditionary troops and Conservative forces on one side, and Benito Juárez and his Liberal loyalists on the other, the Sierra Cora served as a 'zone of refuge, rearguard actions and guerrilla warfare.' Various Cora communities were raided by Liberal militias under the command of Ramon Corona. ${ }^{50}$ Such attacks prompted the ever more direct participation of Cora guerrillas within 'the military forces of the Seventh Canton... as part of the Imperial Auxiliary Troops of Maximilian... receiving five-year salaries and temporary discharges during sowing and harvest times. ${ }^{, 51}$ But testament to his supporters' concerns for local, rather than national, issues, Lozada paid little

\footnotetext{
${ }^{45}$ ABPE, Colección de leyes y decretos de Jalisco, 1860-61, 497

${ }^{46}$ Lira, 'De Buenos Mexicanos,' p.22, citing Peña Navarro, Estudio histórico, 163-165

${ }^{47}$ Pérez González, Ensayo, 416

${ }^{48}$ AGN, Gobernación, 1620, Lozada nullifies 'Tratos de Pochotitán,' 13 June 1862

${ }^{49}$ AHJ, Fomento leg. 1864, Ogazón authorises Millen to recruit colonists, 13 Oct. 1861; Periódico oficial del Gobno. de Sinaloa, 15 April 1862

${ }^{50}$ Lira, 'De buenos mexicanos,' 22-3

51 ibid., 23
} 
attention to French requests for active armed support, and instead concentrated on defeating Corona, taking Tepic, and reasserting order in the Seventh Canton. He remained the master of his own kingdom, pursuing his own agenda, which his ostensible superiors within the French expeditionary forces had no choice but to accept (a policy that, as described by Mario Draper elsewhere in this volume, influenced the attitudes of both French and Belgian forces in their African wars of conquest in the ensuing decades). ${ }^{52}$ Thus General Felix Douay, the senior French officer in the west of Mexico, pragmatically refused to interfere in Lozada's running of the Seventh Canton (which had been officially severed from Jalisco by the new government), admitting that 'General Lozada is not sufficiently subservient to my actions for me to be sure that my orders will be carried out.' 53

Lozada engaged politically with the Imperialists just as he did militarily - when it suited him. Thus it was only in 1865 that he sent his most trusted aide, Carlos Rivas, to Mexico City; his objective was to establish the Seventh Canton permanently as the independent and sovereign state of Nayarit, and to approach Maximilian about the issues that had dominated Lozada's struggles since 1857 - land and indigenous autonomy. An agreement was made: Nayarit was declared a new Department, separate from Jalisco, and the process of communal territorial demarcation was set to begin immediately, the task falling to a committee under the authority of the Ministry of Public Works. ${ }^{54}$ Such contacts between Lozada and Maximilian likely influenced the latter's interest in and sympathy for indigenous issues, which the next year resulted in his passing a wealth of other national-level legislation designed to protect Indian communal lands, and other laws that 'conceded relative liberty to peons, and lands to the indigenous communities that lacked them.' 55

However, despite the Imperial government's support, Lozada was too politically adroit to continue in his adherence to Maximilian's cause after Napoleon III abruptly withdrew French military support in late 1866, and it became clear that the course of the civil war had turned and the Liberals were likely to triumph. Lozada slowly disassociated himself from the Imperialists, declaring, on 1 December 1866, the 'Act of Neutrality of the pueblos of Nayarit.' After suffering a series of defeats throughout early 1867, Maximilian was captured by Liberal forces in May and, the next month, was executed along two of his top generals, Miramón and Mejía. However, Lozada, having freed himself and his followers from any commitments to either of the warring national parties, continued to control a swathe of western Mexico, and began the last phase of his career, as the independent cacique ('political and/or military boss') of Nayarit.

Several years of peace in Nayarit followed, during which time Lozada stepped up the redistribution of lands, and his Cora supporters set about further institutionalising their political, cultural and territorial autonomy through the creation of new civil-military authorities within their communities, whose legitimacy was bolstered through the invention of new ritual practices. With the death of President Juárez in July 1872, however, Lozada's position again became precarious. Internal differences within his ever-heterogeneous political movement which included feuds between rival pueblos as between rival chiefs - manifested themselves with the rebellion of Andres Rosales and Praxedis Núñez, two of Lozada's lieutenants, who took with them a thousand men and the town of Atonalisco. After Lozada defeated them militarily, they fled to the protection of Corona, and would prove instrumental in their former

\footnotetext{
${ }^{52}$ Mario Draper, 'The Force Publique's Campaigns in the Congo-Arab War, 1892-1894,' in this issue

${ }^{53}$ AGN, Archivo de Mariscal Bazaine, Vol. III, fs. 180-186

${ }^{54}$ AGN, Gobernación leg. 1418, Imperial agreement with Lozada, 11 July 1865

${ }^{55}$ Ohmstede et al (eds.), La Presencia del indígena en la prensa capitalina del siglo XIX, 19
} 
leader's eventual downfall. At the same time, with Lozada's protector in Mexico City gone, Liberal elites in Guadalajara and Tepic seized on the opportunity to change the Supreme Government's attitude towards affairs in the Seventh Canton, publishing a glut of damning and openly racist local dispatches in the national press. 'Here there has triumphed at last the huarache [a pejorative term for 'Indian,' after their leather sandals],' reported the Liberal newspaper Juan Panadero from Tepic; 'the entire local government is composed of ignorant unknowns... and the hacendados are still being robbed of their property. Various families are fleeing. ${ }^{, 56}$

As a result, Lerdo declared that Lozada's strongholds must submit themselves to the constitutional order, with Lozada's government replaced with the authority of a jefe politico named by the Supreme Government, and all questions of land boundaries passed to official tribunals, 'without that practiced by [Lozada's] commissions taking place. ${ }^{57} \mathrm{He}$ also ordered the movement of state militias from Zacatecas and Sinaloa to Guadalajara, where they joined forces sent from Colima and Jalisco in anticipation of an attack on Lozada's strongholds. In response, Lozada and his compatriots made the decision to go to war with Lerdo's government at the traditional new-year meeting of all of Nayarit's Lozadista communities, with a first strike launched from the sierra viewed as preferable to waiting to be attacked. On 17 January Lozada proclaimed his 'Plan Libertador' ('Programme of Liberation') to the nation, calling for, amongst other things, the abolition of the land taxes, the governance of the nation by sovereign municipal governments chosen via free elections, and the formation of a council made up of three representatives from each state, again named via free and direct elections, who would decide 'what form of popular representation to give the nation, whether with the character of republic, empire or kingdom, as long as that chosen allows for the nation's true aggrandizement and a lasting peace. ${ }^{58}$

As Lozada's forces took Tepic and then marched towards Guadalajara, the 'Plan Libertador' was essentially ignored by the regional and national press, which preferred to condemn Lozada's movement on the grounds of the supposed savagery of the Coras and other indigenous peoples of the Sierra who supported him. Thus Juan Panadero printed a plea to the government of Jalisco, 'that you take the necessary precautions, so that the appalling tendencies of the Indians are not increased,' without any mention of any political plan whatsoever. ${ }^{59}$ And J.M. Vigil, in a front page editorial in el Siglo XIX, wrote of 'these savage tribes of Álica amongst whom there does not exist even the shadow of individual rights, nor the most remote façade of respect for the interests of society,' and characterised the conflict as the 'crusade of civilisation against the most disgraceful barbarity,' without a single reference to the openly declared goals of Lozada and his supporters, Cora and mestizo alike. ${ }^{60}$

For around a century afterwards, such Liberal propaganda defined interpretations of Lozada and his movement; for history is written by the victors, and on 28 January 1873, Lozada was defeated by Corona at La Mojonera, at the gates of Guadalajara. His primarily guerrilla forces were poorly trained and ill-equipped for a conventional battle against a fortified defensive force, and were routed with heavy losses. His movement shattered with the weight of the blow and Lozada was forced back into the Sierra Cora, where his dwindling forces faced off against ' 10 mil soldados dirigida por tres secciones que penetraron la Sierra de Nayarit por rumbos

\footnotetext{
56 Juan Panadero, 29 September 1872

${ }^{57}$ Ibid.

${ }^{58}$ Lozada, Plan Libertador, 17 Jan. 1873

59 Juan Panadero, in el Siglo XIX, Jan 251873

${ }^{60}$ J.M. Vigil, editorial in el Siglo XIX, Jan 281873
} 
distintos. ${ }^{61}$ As the months went by, he was abandoned by one after another of his chiefs, including, finally, Dionisio Gerónimo and his Cora fighters. After several more months of pursuit, Lozada was eventually captured, taken back to Tepic, and executed. President Lerdo appointed a Jefe Politico (political chief )in his place, although in much of what had been the Seventh Canton - now officially a Federally-administered 'Military District' named for its capital, Tepic - Lozada's former lieutenants remained the paramount local authorities.

Lozada lost more than just a battle at La Mojonera; he lost a war of words that had raged since 1857. To many today, Lozada remains a traitor who sold himself to the French; he is never a marginalised campesino rising up in the name of the exploited, both indigenous and mestizo, against unfair Liberal reforms. Perhaps the charge of treachery stands; but if Lozada was a traitor to Mexico, he was never a traitor to his real homeland - for he stayed true to the pueblos of Nayarit, and above all to the Coras. What use had they for a newly created nation that had already declared them obsolete? What was siding with the French to a people threatened by armed American settlers hired to carry out a genocide in the Sierra?

Thus in the Sierra Cora today, Lozada is still venerated by local people, associated with Jesus Christ and believed to have been betrayed and killed by 'Jews' not in Jerusalem, but in Mexico City; while many of the Coras' Huichol neighbours also associate Manuel Lozada with 'the promethean deer god Kayumarie. ${ }^{62}$ Furthermore, although after the fall of the Second Mexican Empire most of the indigenous groups that had supported Maximilian and the French - such as Sonora's Opata people - were crushed militarily and lost nearly all of their remaining lands and political autonomy, ${ }^{63}$ Cora support for Lozada, followed by their defection to the government side at the last minute, allowed their communities to retain their de facto political and territorial autonomy into the late nineteenth century. Not a single Cora appears to have been involved in litigation with a hacienda during the Lozada era, suggesting that, unlike most of the mestizo communities that supported Lozada, his Cora followers had successfully managed 'la recuperación de sus territorios de las manos de los vecinos desde los sucesos de 1858. ${ }^{64}$ Meanwhile, after Lozada's death, Cora leader Dionisio Gerónimo remained the Sierra Cora's chief politico-military authority, charged by the federal government with keeping the local peace and ensuring that his compatriots abstain from active rebellion against the Liberal order, in exchange for federal non-intervention in local issues.

\section{Part 3: The Porfiriato}

The support of the Cora communities for Manuel Lozada had not only allowed them to expel mestizo settlers from their territories, but also made the application of early Liberal 'reform laws' in the Sierra del Nayar impossible. New pressures were unleashed on the region after Porfirio Díaz overthrew President Lerdo in November 1876 and established a new Liberal regime, which developed into a durable military dictatorship that lasted until it was overthrown during the Mexican Revolution in 1911. However, despite the backing of Díaz's regime for the division and privatisation of communal lands in the Territory of Tepic, which was one of the ten entities most affected by the disentailment of communal lands during the Porfiriato, ${ }^{65}$ continued Cora recalcitrance, together with the difficulties of transport and communication presented by the rough terrain of the region, continued to obstruct the surveying and dividing

\footnotetext{
${ }^{61}$ Lira, 'De buenos mexicanos,' 25

${ }^{62}$ Liffman, Huichol Territory, 65

${ }^{63} \mathrm{cf}$. Yetman, The Opatas, 243-4

${ }^{64}$ Lira, 'De buenos mexicanos,' 24-5

${ }^{65}$ Meyer, De cantón, 162-3
} 
of Cora communal lands. ${ }^{66}$ Thus the Cora communities escaped largely unscathed, with the exception of San Juan Peyotán, which was fully colonised by mestizos. ${ }^{67}$

Similarly, although 'auxiliary courts' were set up in each community to represent the Porfirian state, these were either ignored by the Cora population, or alternatively their judges 'obeyed in all respects the community's [Cora] governor, ${ }^{68}$ having been integrated into existing Cora authorities 'through strange ceremonies.' 69 Throughout the Porfiriato, then, each Cora community retained its control of large tracts of land, as well as a high level of cultural and political autonomy from the state. The Coras remained fiercely defensive of this fact: the Norwegian explorer Carl Lumholtz, who visited the Sierra in the late nineteenth century, noted that, in general, the Coras had 'very strong objections to unions with [mestizos], ${ }^{70}$ while contemporary ethnologist Konrad Preuss reported that 'who do not wish to know anything of the outside world,' describing the Coras as 'haughty subjects, who handle weapons very well and whom one does not wish to bump into in the mountains. ${ }^{71}$ And although the Porfirian state by now regarded the Sierra Cora as 'pacified territory, ${ }^{, 72}$ and Lumholtz and various other foreign visitors, in line with the positivism and social Darwinism that dominated contemporary views of indigenous societies, ${ }^{73}$ predicted that the Coras would soon become culturally and racially extinct, ${ }^{74}$ the Czech doctor and anthropologist Ales Hrdlicka was ultimately correct when he noted that the Coras had 'not given up the thought of armed resistance' to the threats that outsiders posed their lands, cultures and ways of life. ${ }^{75}$

\section{Part 4: The Revolution}

In October 1910, after fraudulent elections in which Porfirio Díaz won a landslide victory, dissident political leader Francisco I. Madero issued his 'Plan de San Luis Potosí,' urging the nation to rise up against the dictatorship on 20 November. Across the country, peasants, workers and members of the provincial middle classes answered Madero's call, setting in motion the Mexican Revolution. The uprising soon reached the mountains separating Durango and Zacatecas from the then-Federal Territory of Tepic. Although in response an expeditionary force of cavalry and rurales set out from Tepic for the Sierra Cora, 'with the object of protecting those distant pueblos and avoid the invasion that the rebels of Durango and Zacatecas might carry out, ${ }^{, 76}$ it failed to achieve its objectives. Rebel forces took the Sierra and marched on Tepic itself, which fell to Maderista forces in May 1911, without a shot being fired. ${ }^{77}$ A few days later Madero and Pascual Orozco defeated the Federal army at Ciudad Juárez, and forced President Díaz from power.

However, the power-hungry Pascual Orozco soon revolted against Madero, and was seconded

\footnotetext{
66 ibid., 139-49

${ }^{67}$ Preuss, Fiesta, Literatura y Magia, 84

68 de la Cerda, 'Los Coras,' 111

${ }^{69}$ AHSEP-84-85/C/38877, E/36, Navarro to DEFN, 26 Oct. 1927; cf. Coyle, From Flowers, 135-8

${ }^{70}$ Lumholtz, Unknown Mexico,. 491

${ }^{71}$ Preuss, Fiesta, Literatura y Magia, 172

72 Pérez, Ensayo estadístico, 10

${ }^{73}$ Dawson, 'From Models,' 291;

${ }^{74}$ Lumholtz, Unknown Mexico,i, xvi; cf. Preuss, Fiesta, Literatura y Magia, p.91

${ }^{75}$ Hrdlicka, Observations, 35

${ }^{76}$ AHSDN-C/C/105/E/XI/481.5/187, Mariano Ruíz to Sec. de Guerra, 27 Mar. 1911

${ }^{77}$ Meyer, De cantón, 191
} 
in Tepic by an ex-Federal Lieutenant, Miguel Guerrero, who raised a force that raided along the western edge of the Sierra Cora. ${ }^{78}$ Guerrero then joined forces with Camilo Rentería in Huaynamota, in the Sierra Cora itself, ${ }^{79}$ and together the rebels attacked Tepic on 29 April. Although they were repelled with losses - to the extent that the Federal commander claimed that Rentería himself had died in the battle ${ }^{80}$ - the city's elite were alarmed by the sudden appearance of a rebel army at their gates, and the Cámara Nacional de Comercio de Tepic warned President Madero that:

'this city does not possess a sufficient garrison of federal soldiers commanded by a skilful military chief... [given] the threat posed by the numerous armed subversives and the Indians of the Sierra... It is well known that the intention of ex-Lieutenant Guerrero is to take control of Tepic and gather together here the elements necessary to then attack the city of Guadalajara, and we invoke the unfortunate memory of the chieftain Lozada, to remind you of the damage that a resolute man can cause the nation once he has taken Tepic. ${ }^{, 81}$

Although references to Indian rebellion had long been used by the elites of both Tepic and Guadalajara to tarnish political opponents like Manuel Lozada, ${ }^{82}$ and to elicit Federal intervention in local disputes by invoking the spectre of a Yucatan-style 'caste war, ${ }^{, 83}$ the Cámara's appeal probably also reflected the real presence of Coras from the area around Huaynamota amongst Rentería's troops. And just as the memory of Lozada remained a byword for the dangers of Indian rebellion amongst Tepic's elite, so too it seems likely that those Coras and Huichols who decided to join Rentería - himself a descendent of one of Lozada's lieutenants - were encouraged to do so by memories of their former successes under Lozada. ${ }^{84}$

The fears of Tepic's elite were soon confirmed, for news of Renteria's death proved premature, and it transpired a month later that the rebel leader was in fact alive and well and back in Huaynamota at the head of two hundred fighters. ${ }^{85}$ Rentería and Guerrero's forces skirmished with Federal troops throughout the summer, and by July the number of 'bandits' active in the Territory had reached more than eight hundred men. ${ }^{86}$ The use of the term 'bandit' by the authorities to disparage revolutionary forces was common throughout Mexico in this period, but it is important to note that many early revolutionary leaders - including such major figures as Emiliano Zapata - had much in common with Hobsbawm's figure of the 'social bandit', and often struggled to form cohesive social movements from the even more 'bandit-like' local rebels who formed the backbone of their forces. ${ }^{87}$ In the Sierra Cora, the depredations of the latter turned local people against Rentería, and, angered by Rentería's attempts to levy 'forced loans' on them, attacked his men and forced them to flee the region in disarray. ${ }^{88}$

\footnotetext{
${ }^{78}$ AHSDN-C/C/105/XI/481.5/188, Unsigned military report, 28 Mar. 1912

${ }^{79}$ Flores, Flores Sánchez, Memorias políticas, 29

${ }^{80}$ AHSDN-C/C/105/XI/481.5/188, Unsigned military report, 29 Apr. 1912

${ }^{81}$ AHSDN-C/C/105/XI/481.5/188, Reps of Cámara Nacional de Comercio, Tepic, to Madero, 11 May 1912

${ }^{82}$ Pérez, Ensayo estadístico, 560; López, Fuego, 150

83 cf. Rugeley, Yucatán's Maya Peasantry, pp.33-60; cf. Nugent, Spent Cartridges, 95-6

${ }^{84}$ Memories of Lozada remained strong in both Cora and Huichols communities well into the twentieth century, cf. Jaúregui, Meyer (eds.), El Tigre de Alica; Lumholtz, Unknown Mexico, 1, 491-2. Indeed, in the 1900s some of his former Cora fighters were still alive and well see Preuss, Fiesta, Literatura y Magia, 172), while given that many Huichol Cristeros in the 1920s viewed themselves as successors of their Lozadista forebears, the same likely goes for Huichol rebels in the 1910s, cf. Meyer, Manuel Lozada: El Tigre, 229.

${ }^{85}$ AHSDN-C/C/105/XI/481.5/188, Juan Castillo to Sec. Guerra, 22 May 1912

${ }^{86}$ AHSDN-C/C/105/XI/481.5/188, Unsigned military report, 8 July 1912

87 Joseph, 'Caciquismo and the Revolution,' 200-1; cf. Hobsbawm, Bandits

${ }^{88}$ AHSDN-C/C/124/XI/481.5/250, J. Arzamendi to Sec. Gob., 23 July 1912
} 
In February 1913, over the course of the ten days known as the Decena Trágica, President Madero was deposed and then assassinated by his foremost military chief, General Victoriano Huerta. Revolutionary military commanders and reformist statesmen including Venustiano Carranza, Francisco ‘Pancho' Villa, Emiliano Zapata and Álvaro Obregón turned their arms on Huerta and eventually defeated his Federal army in July 1914. However, tensions then grew between Carranza and Obregón on one side, and Villa and Zapata on the other. A new civil war soon broke out between the rival revolutionary factions. After Villa was heavily defeated in the Bajío in spring 1915, some remnants of his dispersed army took refuge in the Sierra Cora, pursued by Carrancista forces. This development served to further increase contacts both friendly and hostile - between the Coras and armed outsiders, and paved the way for the local establishment of Carrancista-armed self-defence militias, which, according to one rather disapproving observer, transformed 'savages with bows and arrows' into 'savages with carbines and mausers. ${ }^{89}$ In turn, this led to the rise of a new generation of Cora leaders who can be defined, according to Alan Knight's cacical grading system, as bottom-level, local (or even sub-local) 'caciquillos,' some of whom survived the revolution to emerge, in the 1920s, as higher-level 'municipal' or even 'regional' caciques. ${ }^{90}$

Some Cora Defensas were formed after the Carrancistas occupied a community, met with the traditional authorities, charged them with selecting a suitable leader or picked one out from amongst them, and made them responsible for organising a militia. In other cases, regional Carrancista commanders lent official recognition to pre-existing Cora paramilitaries, on condition they pledged their allegiance to Carranza. The Carrancistas would then hand over whatever arms they could spare (generally bolt-action cerrojo rifles), although there were often fewer weapons than needed, and many Defensa members initially armed themselves with bows and arrows, slings, machetes, or the ever-versatile coa digging stick. As in other peripheral regions of Mexico, the size of the Cora Defensas varied from five to more than forty members, ${ }^{91}$ and often grew or shrank according to the availability of weapons, the severity of external threats, and the value of the prizes to be won through armed action. ${ }^{92}$

Those who ended up heading the Defensas, whether elected by their communities or handpicked by the Carrancistas, tended to be young men able to mediate between their communities and the outside world. Given the long histories of contact between the Coras and the regional mestizo population, and the way in which the shamanic practices of the former often required individuals to take on multiple contradictory identities, there were always a few Indians in each community able to act simultaneously as 'Indian and mestizo'. ${ }^{93}$ In a few cases, these men were themselves mestizos, albeit with close ties to the local Cora majority. If they had some military training, their command of a Defensa was all the more authoritative; so much the better if they were wealthy (in this period synonymous with cattle ownership), and therefore had the means to supply some of a Defensa's material needs, and more to lose from Villista raids.

\footnotetext{
${ }^{89}$ AHAG-Totatiche/C/3/E/13, Magallanes to Arz., 6 July 1920

${ }^{90}$ Knight, 'Caciquismo,' 27-9

${ }^{91}$ In the Oaxacan highlands, communal Defensas averaged five or six members, but several regional caciques commanded from eighteen to thirty-one fighters (Smith, Politics and Pistoleros, 67). Similar ranges are given for the Defensas of the mestizo regions of Zacatecas and Jalisco that bordered the Gran Nayar (I. Landa, in Caldera, de la Torre, Pueblos, 49; P. Landa, in ibid., 55-56)

${ }^{92}$ For example, when Mariano Mejía, usually the commander of an eleven-man Defensa in Jesús María, faced a serious military threat, he could assemble a combined force of around one hundred fighters drawn from communities across the Cora Alta; cf. interviews with Enendino Escobedo Mejía; Juventino Mejía Rivera; Cándido Contreras Rosales.

${ }^{93}$ Neurath, 'Contrasting Ontologies,' 15 (emphasis author's own)
} 
The Defensas of the Sierra Cora played an important part in Carrancista efforts to combat remnant Villistas and generalised banditry in the Territory of Tepic. After Carranza elevated the Territory to the category of a 'Free and Sovereign State' in January 1917 - named Nayarit after the Cora endonym, Naayari ${ }^{94}$ - they consolidated their power through an alliance with the new state's governor, General Jesús M. Ferreira. By early 1919, when General Francisco de Santiago seized power in Nayarit, ${ }^{95}$ de facto control over the entire Sierra Cora lay in the hands of two Carrancista-aligned Defensa commanders: Mariano Mejía and Eutimio Domínguez.

Domínguez was a full-blooded Cora born in $1882 .{ }^{96}$ His father was also a native of San Juan and a relatively wealthy rancher, while his mother, according to some accounts, was originally from San Francisco - reflecting the strong links of trade, kinship and ritual which still linked together the different Cora communities. Domínguez seems to have been an early participant in the revolution in Nayarit, eventually returning home with a wounded knee (which would never fully heal, forcing him to spend most of the rest of his life on horseback), ${ }^{97}$ and the rank of Colonel in Carranza's Constitutionalist army. ${ }^{98}$ There he established a Defensa to defend both his community, and his father's cattle, from the raids of the 'bandidos' then active in the area. ${ }^{99}$

After his father's death in one of these raids, Domínguez inherited what was left of his herds. ${ }^{100}$ This enabled him to sponsor ceremonies that increased his status within the descent-groups groups that he belonged to, while his status as a ranking military officer, and his command of a well-armed Defensa, limited the opposition of rival families or factions to his increasing influence in San Juan and neighbouring communities. He not only appeared to his Cora compatriots as 'one of us', but also as a natural leader possessed of supernatural powers. He was known to spend much of his time fasting and praying to his community's santitos, 'so that nothing would happen to his men.' Thanks to Domínguez's asceticism, the five devoted bodyguards who always surrounded him in battle were reputed to have been practically bulletproof, their white cotton shirts and trousers 'all shot full of holes, but not even a scratch on their bodies. ${ }^{\prime} 101$

However, Domínguez also spoke good Spanish, had learned to read and write while in the army, and his intellect would later impress SEP officials, who rather patronisingly described him an 'Cora Indian of relative culture. ${ }^{102}$ Like other indigenous caciques in this period, from Oaxaca to Michoacán, he used his literacy, charisma and military prowess to successfully negotiate the violent and alien world of revolutionary mestizo politics, while also playing up his ethnicity in order to present himself as a 'noble Indian'. ${ }^{103}$ Thus Domínguez acted as a bridge between Coras and outsiders, allowing him to consolidate his influence over the rest of

\footnotetext{
${ }^{94}$ Meyer, Del canton, 192

95 ibid., 193

${ }^{96}$ AGN-Censo/1930/Nayarit/San Juan Corapan

${ }^{97}$ Filiberto Sánchez, 'Aurelio Chavez'

${ }^{98}$ AHSEP-84-85/C/38876/E/17, Orozco to DEFN, 9 Feb. 1928

${ }^{99}$ Interviews with Sandalio Sánchez; Filiberto Sánchez; Agustín Lamas

100 Interviews with Erasmo González and Filiberto Sánchez;

${ }^{101}$ Interviews with Filiberto Sánchez, Sandalio Sánchez, and Celestino Lamas

${ }^{102}$ AHSEP-45/C/36301/E/29, Navarrete to DECI, 4 May 1925

103 Purépecha leader Primo Tapia, and Juchiteco strongman Heliodoro Charis, were also notably successful in using their Indian identity to their advantage in their dealings with both local support bases and external, mestizo authorities; cf. Friedrich, Agrarian Revolt, 71-2; Smith, Pistoleros and Popular Movements, 141-2
} 
the Cora Baja - whose communal Defensas Rurales were all under his control by 1920 - while simultaneously developing his clout with the state government, which would later come to depend on him to harness the collective military potential of the Coras during the first Cristero rebellion.

Domínguez's friend and then-ally Mariano Mejía was an even more powerful figure. Unlike the Cora Domínguez, Mejía was born 1879 in increasingly 'mestizoised' Huaynamota, ${ }^{104}$ and oral sources agree that his mother was a local 'Indian', ${ }^{105}$ and his father a mestizo rancher. Although unable to speak the Cora language, ${ }^{106}$ and despite traditional Cora distrust towards mestizos, Mejía nonetheless managed to become one of the many 'white and mestizo ethnic brokers' to raise a powerful and predominantly Indian force during the Revolution, ${ }^{107}$ and by 1920 he represented Carranza's government throughout the entirety of the Cora Alta and beyond into neighbouring parts of Durango and Jalisco. ${ }^{108}$

Mejía had been orphaned while still a young boy, after 'revolutionaries' - most likely exLozadista rebels - killed his father, and his mother fled the community. ${ }^{109}$ Mejía's uncle, a priest, adopted the boy and took care of his education, ${ }^{110}$ which allowed him to become, like Domínguez, one of the few literate natives of the Sierra Cora at this time. Mejía arrived in Jesús María some years before the outbreak of the Revolution, after his uncle was sent there to serve as a parish priest. Mejía was able to use the inheritance left him by his late father to buy cattle and set himself up as a rancher. ${ }^{111}$ His herds increased rapidly, and he became a rich - and thus influential - local figure, hiring Coras and mestizos from across the region to work on his ranch, ${ }^{112}$ and thus establishing patron-client ties with his neighbours. ${ }^{113} \mathrm{He}$ also married a Cora woman and established Catholic-style ritual kinship ties with other Coras through the institution of compadrazgo.

As a rich and literate local mestizo who also commanded the respect of many Coras, Mejía had huge potential to become a 'revolutionary' cacique in the serrano tradition, ${ }^{114}$ while his extensive herds would have been natural targets for the Villista bands roaming the Sierra. It is not surprising, then, that at some point during the revolutionary upheaval, ${ }^{115}$ Mejía obtained arms from the Carrancistas for himself and eleven men - probably selected, as usual, from amongst his peons, in-laws and compadres ${ }^{116}$ - to set up a local militia. ${ }^{117}$ Only after he had

\footnotetext{
${ }^{104}$ AGN-Censo/1930/Nayarit/Arroyo de Santiago

${ }^{105}$ Oral sources are unclear as to her actual ethnicity.

106 Interviews with Enendino Escobedo; Juventino Mejía; Cándido Contreras

107 Many Mayos, Yaquis and Juchitecos went into battle behind mestizos during the revolution. Fallaw and Rugeley suggest that this 'suggests that Mexican armies reproduced inequality, [and] remained very much a bastion of mestizo culture' ('Redrafting History,' 16-17)

108 AHSEP-45/C/36301/E/29, San Lucas de Jalpa, to Pres., 12 Mar. 1925; AHJ-G-9-920-921/C/52/E/11171, Clemente Villa to Gob.Jal., 17 Feb. 1921

${ }^{109}$ Enendino Escobedo; Juventino Mejía; Cándido Contreras

${ }^{110}$ Juventino Mejía

${ }^{111}$ Enendino Escobedo

112 Juventino Mejía; cf. Coyle, From Flowers, 185-6

${ }^{113}$ Scott, 'Patron-Client Politics,'.92

114 Knight, The Mexican Revolution, i, 115-27; cf. Brewster, Militarism, Ethnicity, and Politics; Rugeley, Yucatan's Maya Peasantry, 101

115 Perhaps in late 1916, when the Defensas Sociales of Chihuahua were also first established by Carrancista General Enríquez (Almada, La revolución,ii, 326); cf. Nugent, Spent Cartridges, 83

116 Torres notes that these same relationships defined factional politics amongst the Nahuas of highland Puebla; Cf. 'Nahuat Factionalism,' 467-8

117 Enendino Escobedo; Cándido Contreras
} 
actively demonstrated his loyalty to the Carrancistas, however, was Mejía able to extend his authority beyond his base in the Jesús María region. According to local interviewees, at some point during the revolutionary civil war a rebel leader called José Gallegos, most likely a Villista from Zacatecas, took refuge in the Sierra Cora. ${ }^{118}$ However, the Constitutionalist authorities in Tepic soon heard of his presence, and ordered Mejía to assassinate him. Mejía accordingly invited Gallegos to join his Defensa in a raid on 'bandits' supposedly hiding out in the forests around Santa Teresa, and then betrayed and murdered him as they ate lunch in the mountains.

The versions of this story told by Mejia's grandsons, Juventino Mejía Rivera and Enendino Escobedo Mejía, attribute supernatural powers to Gallegos, who was rendered invincible by a huge tattoo of a devil across his back. It was only after Mejía and his men 'cut off the skin with a knife, all that had the devil on it, that Gallegos then finally began to die. ${ }^{119}$ Although it is not surprising that Mejía's descendents should exaggerate the powers of Gallegos - and thus of the famous forebear who managed to dispatch him - the other details of their stories, such as the cruelty of Gallegos' murder, are typical of many local tales of the revolution and the Cristiada. ${ }^{120}$ Meanwhile, the mythical elements of the story - and the way in which having vanquished Mejía is said to have taken on the dead Villista's powers ${ }^{121}$ - fit within a welldocumented Latin American tradition of attributing supernatural qualities to influential leaders, ${ }^{122}$ which in turn served to bolster their charismatic power and further legitimise their authority. ${ }^{123}$ In Mexico, Emiliano Zapata is the most famous example of how such processes of mythification and mystification function, ${ }^{124}$ but much the same could also be said of Eutimio Domínguez, and, more importantly, of Manuel Lozada, to whom many older Coras and Huichols still attribute supernatural powers. ${ }^{125}$

Even discounting the similarities between the supernatural tales told about Mejía and Lozada, it seems clear enough that the general precedent set by the latter must have helped boost local acceptance of Mejía's influence some fifty years later. Just as Lozada, aided by his Cora lieutenant Dionisio Gerónimo, had overcome traditional Cora antipathy towards mestizos to rise to power over the entire Sierra Cora, so too Mejía was helped by a Cora compadre, León Contreras, to rise from commanding eleven men in Arroyo de Santiago, to controlling the Defensas of every Cora and mestizo community in the Cora Alta. His influence even extended beyond state lines as far as Huazamota and San Lucas in Durango, ${ }^{126}$ and San Andrés in Jalisco; ${ }^{127}$ which, significantly, were also the only communities outside of the Territory of Tepic to sign Lozada's 1870 political manifesto, ${ }^{128}$ further reflecting the parallels between the two men's careers and spheres of influence. Nugent has noted the 'importance of popular forms of historical memory and their strategic deployment in political struggle' during the revolution, ${ }^{129}$ and it would seem that Mejía successfully tapped into Cora memories of Lozada's 'Popular

\footnotetext{
118 Juventino Mejía; Enendino Escobedo; Cándido Contreras

119 ibid.

${ }^{120}$ cf. Caldera and de la Torre, Pueblos; de la Torre, 1926

121 Juventino Mejía Rivera

122 eg. Reichel-Dolmatoff, The People of Aritama, 15-6

${ }^{123}$ Weber, On Charisma, 19; see also Lomnitz-Adler, Exits from the Labyrinth, p.350

${ }^{124}$ Brunk, Emiliano Zapata, 238-9; cf. Brewster, Militarism, Ethnicity, and Politics, pp.57-61

${ }^{125}$ Jauregui and Meyer (eds.), El Tigre de Alica; cf. Neurath, Las fiestas, p.229; Alvarado, Atar la vida, p.299-300

${ }^{126}$ AHED-FR/C/5/E/54, Mariano Mejía to D. Arrieta, 24 July 1919; AHSEP-45/C/36301/E/29, Residents of San Lucas de Jalpa to Gob. Dgo., 12 Mar. 1925

${ }^{127}$ AHJ-G-9-920-921/C/52/E/11171, Clemente Villa to Gob. Jal., 17 Feb. 1921

${ }^{128}$ Aldana, La rebelión agraria, 181-209

${ }^{129}$ Nugent, Alonso, 'Multiple Selective Traditions,' 244
} 
Conservative' rebellions so as to unite them against the bandits and Villistas who now threatened their communities, just as Mejía's contemporaries elsewhere in Mexico mobilised their own indigenous clients through similar references to their forebears' participation on the Liberal side during the Wars of Reform. ${ }^{130}$

The ability of Mejía and Domínguez to establish themselves as paramount authorities in the Sierra Cora no doubt owed much to the prior existence of a centralised politico-military command amongst the Coras, both during the rule of Lozada, and in the era of the Rey Nayar. In turn, by calling together all of the Defensas of the Sierra Cora to undertake larger-scale military operations, Mejía and Domínguez boosted their effectiveness as military commanders, and thus the strength of their claims to legitimate military and political authority over the region and its inhabitants.

Using the same guerrilla tactics that had made them such effective fighters during Lozada's rebellion and many other, previous conflicts - and, in addition to the occasional cerrojo rifle, weapons such as bows and arrows, machetes, boulders, and the careful use of fire to burn their enemies out of their strongholds or sow panic amongst them during night-time ambushes ${ }^{131}$ they were not only able to defend their communities against raiders, but also played an important role in Francisco de Santiago's pacification campaign in Nayarit in 1919 (to the extent that Mejía was on first name terms with the general). Their alliance with the Revolution's 'winning side' won the cacical regimes of Mejía and Domínguez the state government's full recognition. ${ }^{132}$ And their unifying influence not only helped to strengthen the Coras' collective ability to defend themselves, but also impeded the outbreak of internecine conflicts that might otherwise have fractured the bonds between their communities. This brought to the region a level of political stability that local people initially welcomed after the chaos of the early years of the revolution.

However, although the emergence of the Cora Defensas, and the rise of their commanders to political importance, had important conceptual and historical antecedents, local war leaders of previous eras had tended to recede into the political background once the immediate military threat had passed. Many of the Cora Defensa-commanders-turned-caciques of the revolutionary period, however, were reluctant to give up their newfound power and growing wealth even after the threat of Villista raids began to fade. From 1919, as their original raison d'être ebbed, the Sierra Cora's Defensa commanders sought to preserve their status by entering into increasingly close alliances with the emergent revolutionary state. In response, popular resistance to their authority grew, engendering factional conflicts throughout the region's communities, and locally validating Knight's general judgement that 'the only good cacique is - if not a dead cacique - at least a short-lived cacique. ${ }^{133}$

\section{Part 5: Epilogue}

\footnotetext{
130 cf. Joseph, 'Rethinking Mexican Revolutionary Mobilization,' 157-65; Mallón, 'Reflections,' 98-100. Given that Lozada's 'Conservativism' and Juárez's 'Liberalism' are both remembered locally as struggles for land and autonomy, peasants on both sides of the War of Reform were obviously more concerned with these ubiquitous goals than with the political labels that elite actors attached to their causes. 'Popular Liberalism' and 'Popular Conservatism' may therefore have had more in common than is sometimes assumed. After all, as Hobsbawm has pointed out, 'a social social revolution is no less revolutionary because it takes place in the name of what the outside world considers "reaction" against what it considers "progress"' (Bandits, 21)

${ }^{131}$ Bruno Gómez Estrada and Nemesio Rodríguez Rodríguez, Santa Teresa, Nayarit 03/11/2013

${ }^{132}$ AHED-FR/C/5/E/54, D. Arrieta to Mejía, 9 Aug. 1919

${ }^{133}$ Knight, 'Cardenismo,' 97
} 
Although their struggles are less well known than those of the Yaqui, between 1850 and the early 1920s the Coras successfully used guerrilla operations and tactical alliances with outside forces to defend their lands from rapacious hacendados, their political independence from expansionist statesmen, and their culture from the pressures of mainstream, mestizo society. Cora fighters, whether aligned to the pro-independence cause, or to Manuel Lozada, or to the Carrancistas, shared similar objectives and were united by strong, ritually-defined, politicalmilitary ties between their communities, but were also able to move quickly and effectively through the mountainous and heavily forested terrain of their homeland in small groups, giving them an important advantage over their less mobile enemies, who were usually less knowledgeable about the local landscape and less adept at guerrilla fighting.

At all three of these important junctures in Mexican history, collective memories of the priestkingdom that existed in the Cora homeland until the early eighteenth century, filtered through a worldview that stressed the power of supernatural forces in every aspect of life, helped Cora communities to mobilise militias that would defend them against their enemies. Such tactics allowed the Coras to maintain a high level of autonomy compared to most of Mexico's other indigenous groups well into the twentieth century, and also had consequences for the nation as a whole: for instance, Cora participation in Manuel Lozada's rebellion led directly to the creation of state of Nayarit; helped the French to hold onto swathes of western Mexico even as they faced defeat in the country's interior; influenced Emperor Maximilian's indigenous-rights and agrarian policies; and cemented Maximilian's Liberal successors' beliefs in the inherent danger that Indian autonomy posed the nation-state. Later Cora backing for the Carrancistas during the Revolution meanwhile helped the latter establish their control of Nayarit, defeat their Villista rivals at national level, and, it had become clear by the mid-1930s, sowed the seeds for the eventual decline of the Cora communities as politically autonomous entities, even as it won their lands some level of protection from rapacious major landowners and small-time mestizo colonists alike.

The fact is that the growing power of militia commanders in the Sierra Cora, in the context of the concerted state-building efforts of successive revolutionary regimes between 1920 and 1940, served to undermine both the internal stability of the Cora communities and the political and ritual ties that had long existed between them. Most Cora military leaders turned out to be willing to sacrifice some of their autonomy in exchange for territorial protection and personal political and economic advantage; a trade-off that was fiercely resisted by conservative Cora factions, giving rise to internecine conflict throughout the Sierra in the late 1920s, during the Cristero rebellion. However, the defeat of the conservatives by their better-armed, bettersupplied 'cosmopolitan' enemies ensured that the Cora homeland would finally become an indissoluble part of the Mexican nation-state.

Thus in the face of changing national-level conditions, the same Cora militarism that had once propped up their political autonomy, ended up undermining it. Comparisons can thus be made between the Cora paramilitary organisations of the early twentieth century, and many of the indigenous militias that emerged elsewhere in Latin America from the 1950s; for example, the Peruvian rondas campesinas ('peasant patrols'). These played an important part in defeating the country's Maoist 'Shining Path' guerrilla movement, but also pursued communal, factional and personal agendas, and their leaders evolved into powerful warlords, giving rise to factional tensions and social conflicts in the areas in which they were active. ${ }^{134}$

${ }^{134}$ cf. Starn, Nightwatch 
However, although the Sierra Cora of today is far from the priest-kingdom of the Tonatí, or even the autonomous league of indigenous republics that flourished under the regional rule of Manuel Lozada, neither is the Cora homeland as integrated into Mexico as the mid-nineteenthcentury's Liberals, or their Carrancista successors, would have wanted. Thanks to historical Cora resistance and continued recalcitrance, the presence of the state in the region remains weak, and its representatives are primarily coercive forces - like the odd army battalion hunting for opium plantations - or part of agencies offering cash transfers, donations of food or blankets, and offers of political support to the Cora communities on condition that they send their children to schools where they can be transformed into 'Mexicans' through education.

Meanwhile Cora traditional governments and agrarian authorities remain influential within their communities, which continue to hold their lands collectively - anathema both to Liberal conceptions of 'civilised' land tenure and 'modern' political organisation. Meanwhile, although most Coras have now abandoned the idea of protecting their autonomy via active warfare against the state, they continue to employ Scottian 'weapons of weak' - including 'footdragging, noncompliance, evasiveness, and obfuscation,' and the selective use of their language as a code ${ }^{135}$ - to defy the demands and expectations of outsiders such as government officials. Indeed, within the context of the current Mexican 'Drug War,' some of the Cora youth are winning back their forebears' reputation as 'dangerous' and 'wild' Indians, through their active participation, whether voluntary and involuntary, in the international narcotics trade, both in terms of the production of opium, and, increasingly, the trafficking of this and other drugs north towards the US. Thus the pursuit of autonomy through the negotiation of alliances with potentially threatening outside forces - whether this entails taking up arms against the state, or abandoning defeated caciques and fighting for the state - has at the very least allowed the Coras to defy the predictions of nineteenth century statesmen and explores alike, that 'these primitive people will soon disappear by fusion with the great nation to whom they belong., ${ }^{136}$

\section{Author Bio}

Nathaniel Morris is a Leverhulme Early Career Research Fellow at UCL. He is researching the rise of indigenous vigilante groups in the context of Mexico's modern 'Drug War,' and the ties of history, memory, space and culture that link them to indigenous militias that played key roles in the War of Reform (1857-61), and the Mexican Revolution (1910-1940). His particular focus is on the way in which the interactions between communal militias, non-state actors (whether bandits, drug cartels or revolutionary guerrillas), and different government institutions, have helped to shape both the Mexican nation-state, and the diverse ethno-cultural and sociopolitical identities of its inhabitants.

\footnotetext{
135 Scott, Weapons, xvi, 29-35

${ }^{136}$ Lumholtz, Unknown Mexico,i, xvi; cf. Preuss, Fiesta, Literatura y Magia, 91
} 